\title{
REVIEW OF SPECTROPHOTOMETRIC METHODS FOR DETERMINATION OF FORMALDEHYDE
}

\author{
Martina HLADOVÁ ${ }^{1}$, Jozef MARTINKA ${ }^{1}$, Peter RANTUCH ${ }^{1}$, Aleš NEČAS $^{1}$ \\ ${ }^{1}$ SLOVAK UNIVERSITY OF TECHNOLOGY IN BRATISLAVA, \\ FACULTY OF MATERIALS SCIENCE AND TECHNOLOGY IN TRNAVA, \\ INSTITUTE OF INTEGRATED SAFETY, \\ Ulica JÁnA BotTu 2781/25, 91724 TRNAVA, SLOVAK REPUBLIC \\ e-mail:martina.hladova@stuba.sk,jozef.martinka@stuba.sk, rantuch.peter@stuba.sk, \\ ales.necas@stuba.sk \\ Received: 14.05.2019, Accepted: 10.06.2019, Published: 25.07.2019
}

\begin{abstract}
Formaldehyde is a toxic chemical commonly found in the environment. Owing to its increased usage, its incidence has also increased, and there is a need to determine the concentration of formaldehyde for the pollution control purposes. In general, spectrophotometric methods are easy to perform, low-cost, selective and sensitive, but every spectrophotometric method has its advantages and disadvantages, which are an important factor when selecting the method for determination of formaldehyde. Therefore, the aim of the research described in this paper was to compare the current spectrophotometric methods and to summarize their advantages and disadvantages.
\end{abstract}

\section{Key words}

Spectrophotometry, formaldehyde, determination, reagents, UV/VIS spectroscopy

\section{INTRODUCTION}

Formaldehyde (HCHO), is the most commonly found aldehyde in the environment [1]. Owing to its toxicity, it has been classified as one of the most important air pollutants $[2,3]$. The greater significant part of the aldehydes present in the atmosphere comes from the incomplete combustion of fuels, gasoline, and refuse material [4]. Specifically, formaldehyde enters the environment from natural sources (including forests fires) and direct human sources such as fuel combustion, on-site industrial uses, and off-gassing from building materials and consumer products $[5,6]$. Although formaldehyde is necessary for many products and processes essential to the world's economy, this economic dependence comes at a cost to public health [7]. 
Exposure to formaldehyde or its vapours may cause a variety of symptoms or diseases. These include contact dermatitis; headache; eye, nose, and throat irritation; shortness of breath; wheezing; chronic cough; mucus hypersecretion; asthma; chronic airway obstruction; bronchitis; rhinitis; pharyngitis; menstrual and reproductive disorders; and sexual dysfunction [8]. Recently, both the International Agency for Research on Cancer (IARC) and the National Toxicology Program (NTP) concluded that formaldehyde is a known human carcinogen that causes nasopharyngeal cancer and myeloid leukaemia [7]. In the air, formaldehyde is considered as immediately dangerous to life and health at a concentration level of $24 \mathrm{mg} / \mathrm{m}^{3}$, and exposure limit of $90 \mathrm{~g} / \mathrm{m}^{3}$ [9].

Along with a boom in the production and usage of formaldehyde, the incidence of formaldehyde pollution has also increased significantly. Now, the general population faces environmental exposure from indoor air, outdoor air, food, and even medicine, exacerbating this serious public health issue in China, in the US and globally [7].

Recently, there has been a tendency to determine the concentration of formaldehyde in the environmental samples for pollution control purposes and to provide a strict regulatory restriction on the usage of consumer products [6]. The aim of this paper is to summarize and compare advantages and disadvantages of the current spectrophotometric methods for the determination of formaldehyde in the air, and to choose the most suitable methods for safety engineering on the basis of selected criteria.

\section{REVIEW OF THE METHODS AND DISCUSSION}

Chromatography and spectroscopy are generally used to carry out formaldehyde analysis. The chromatographic method is accurate and sensitive, but the instruments are expensive and difficult to promote [10]. Ion chromatography has several drawbacks. There are interferences and significant loss of formaldehyde during desorption from the solid sorbent [14]. Other sensitive methods for formaldehyde determination include voltammetry and fluorometry [6]. From electrochemical methods, polarography has also been used to determine formaldehyde, although this method is not popular. It lacks sensitivity, and other aldehydes interfere. Fluorimetric methods are more sensitive, however, they are difficult to use and have poor reproducibility and fluorescence stability [14]. In comparison with the methods mentioned above, spectrophotometric methods are among the relatively low-cost, simple and sensitive methods and therefore are very popular $[6,11]$. They are commonly used for the determination of small amounts of formaldehyde [5]. The sensitivity of spectrophotometric methods is affected by two factors - the dilution factor and the molar absorptivity (based on the compound analyzed) of the final chromogen. The closer the dilution factor is to one and the higher the molar absorptivity, the greater the sensitivity of a procedure [12].

A large number of reagents have been proposed for the spectrophotometric determination of formaldehyde in the air [3]. These methods are based on the reaction of formaldehyde with reagents, such as Schiff's reagent, p-phenylenediamine, chromotropic acid, brilliant cresyl blue and fluoral-P [6]. According to the used type of reagent, they may be classified into four groups: a) methods depending upon Schiff's type reagents, b) methods using phenolic type compounds, c) methods based on reactions with miscellaneous aromatic compounds, and d) methods based on reactions with inorganic reagents [13].

Pockard (1984) used a different classification of the spectrophotometric methods. He classified them into: a) xanthylium dyes (chromotropic acid, J-acid, phenyl J-acid) b) formazan dyes (aromatic hydrazines and hydrazones in the presence of an oxidizing agent - 2Hydrazinobenzothiazole (HBT), 3-Methyl-2-benzothiazole (MBTH) c) metal complexes (oxalyldihydrazide) d) trimethine dye (1-ethylquinaldinium iodide) e) Hantzsch reaction 
(acetylacetone and ammonia) f) Schiff's reagent (fuschin, pararosaniline, p-aminoazobenzene) [14].

\section{Methods using phenolic type of compounds}

Preliminary studies of a large number of phenolic and other aromatic compounds reported in the literature have showed that only chromotropic acid (1,8-dihydro-xynaphthalene-3,6disulfonic acid) and 2,7-dihydroxynaphthalene were capable of meeting the demands of a reliable colorimetric method [13].

\section{Chromotropic acid}

The chromotropic acid method is one of the available popular colorimetric methods for the detection of formaldehyde in aqueous media. This procedure is also both simple and rapid in its application to the determination of formaldehyde as an atmospheric pollutant or combustion effluent [15]. Spectrophotometric chromotropic acid (CA) method has been recommended by the National Institute for Occupational Safety and Health - NIOSH in its P\&CAM 125, 235 and 3500 reference methods $[11,16]$. The reaction with chromotropic acid in the concentrated sulfuric acid medium was adopted as a standard spectrophotometric method for the determination of $0.02-4.00 \mathrm{~g} \cdot \mathrm{ml}^{-1} \mathrm{HCHO}$ [17]. The method is based on the formation of a characteristic violet coloured compound by the reaction between formaldehyde and chromotropic acid (4,5-dihydroxynaphthalene-2,7-disulfonic acid) in the presence of considerable amounts of sulfuric acid. This mechanism is also applied in the NIOSH method $[13,15,16]$. For atmospheric sampling, formaldehyde in the air is scrubbed into an aqueous solution by way of impingers charged with water, bisulfite solution or a solution of the reagent. The use of reagent was found superior to other solutions for quantitative recovery when a single impinger was used [15]. This spectrophotometric method was developed by Bricker and Johnson in 1945 using chromotropic acid in sulfuric acid [18] and was improved in 1956 by West and Sen by increasing the sulfuric acid strength to greater than 86\% [13].

This method is sensitive and selective. However, the major drawback present by CA method has been the use of hot concentrated sulphuric acid or the use of a less harmful mixture of $\mathrm{HCl}$ and $\mathrm{H}_{2} \mathrm{O}_{2}$ [5], which have been proposed by Fagnani (2003) [19]. $\mathrm{H}_{2} \mathrm{SO}_{4}$ is potentially hazardous and corrosive, and the requirement of heating the resulting solution for about one hour in a steam bath $\left(100^{\circ} \mathrm{C}\right)$, making its utilization less attractive in routine analysis $[11,16]$.

Gasparini et al. (2008) eliminated the use of strongly acidic media and advantageously replaced by magnesium sulphate, which is benign to humans and the environment. The method allows the determination of formaldehyde at low operating cost and shows simplicity, adequate selectivity and requires only standard lab equipment. The method is based on formaldehyde reaction with chromotropic acid in the presence of magnesium sulphate producing a stable complex $\mathrm{Mg}^{2+} /$ cyclotetrachromotropylene $(\lambda \max =535 \mathrm{~nm})[11]$.

Gigante et al. (2004) proposed a simple and effective method in which replaced highly corrosive acid as $\mathrm{H}_{2} \mathrm{SO}_{4}$ and heating in a steam bath at $100{ }^{\circ} \mathrm{C}$ for a mixture of $\mathrm{H}_{3} \mathrm{PO}_{4}$ and $\mathrm{H}_{2} \mathrm{O}_{2}$ assisted by a microwave oven. The coloured compound has been completely formed within 35 s of microwave irradiation. They applied this method to the analysis of formaldehyde used as the active ingredient in commercial disinfectants [16].

Others drawback involving spectrophotometric methods are low colour stability, interference of many substances or preconcentration step [5]. However, according to Altshuller (1961) the interference of sulfites and aldehydes, other than acrolein, has been reported to be negligible, since formaldehyde is usually in considerable excess over any of the other individual aldehydes in combustion gases and the atmosphere [15]. This statement coincides with the West 
and Sen (1956) [13] and Georghiou and Ho (1989) [20], who claimed, that among the aldehydes only acrolein seriously interfered. On the other way, Lyles et al. (1965) claimed, that this method suffers from numerous interferences, both organic and inorganic in nature. According to them, many common inorganic interferences pose serious difficulties with this method [21]. Formaldehyde-releasing compounds, such as piperonylic acid, anisyl alcohol, and dextrose, also react [12].

In terms of interferences, this method was also improved by Jendral et al. (2011), who used this method to determine formaldehyde in alcoholic beverages. For improvement, they used multivariate analysis for eliminating interferences of other compounds that led to yellowing/browning of the solution. Using multivariate curve deconvolution expands its use to matrices that would be normally excluded due to spectral interferences. They claimed that the determination of formaldehyde in alcoholic beverages using chromotropic acid is not possible without a chemometric method. The advantage of the overall procedure is that it is simple, reliable and cheaper than chromatographic methods [22].

\section{2,7-dihydroxynaphthalene}

Characteristics of 2,7-dihydroxynaphtalene are very much similar to those of chromotropic acid. After dissolution in concentrated sulfuric acid, it produces a colour with formaldehyde similar to that produced by chromotropic acid under like conditions, the region of maximum absorption being at $540 \mathrm{~nm}$. The colour reaction is more dependent upon acid concentration, and there are no limits of acid concentration between which the intensity of the colour is completely independent of acid concentration. The reaction has identical sensitivity as with chromotropic acid. The reagent solution has a grey colour with bluish fluorescence. This reagent also has selectivity similar to that shown by chromotropic acid. Acrolein seems to be the only seriously interfering substance, and its interference can be much diminished by slightly modifying the standard procedure [13].

\section{Shiff method}

\section{Fuschin}

Schiff (1866) reported that the colour of a Solbleached fuchsin solution was regenerated upon the addition of an aldehyde [23]. Rayner (1961) increased the depth and stability of the colour by using Schiff's reagent (Fuschin) in combination with acetone. This method is sufficiently sensitive to determine the low concentration of formaldehyde in the air. When Schiff's reagent is added to formaldehyde solutions, the amount of colour produced depends upon the acidity, temperature, time, and formaldehyde concentration. A level of 5 p.p.b. of formaldehyde in the air can be determined if 60 cubic feet are sampled. The precision of the analytical method, using test solutions containing 5 and $10 \mu \mathrm{g}$. of formaldehyde, is 8 and $4 \%$, respectively. Acrolein gave a colour with Schiff's reagent and interfered when present in greater amounts than formaldehyde. Other interferences are acetaldehyde, sulphur dioxide, oxides of nitrogen [4].

The Schiff's method, though very old and widely used, suffers from numerous defects and many modifications have been suggested in attempts to evolve a satisfactory test. A comparative study of the different types of Schiff's reagents reported by various investigators showed that in general procedures employing this reagent have a very low reproducibility because of the numerous variables involved [13]. The Schiff test also does not satisfactorily follow Beer's law, whereas the other procedures do [12]. Relatively slow colour development, limited sensitivity $[24,25]$ and interferences from co-pollutants are the main drawbacks of methods based on Schiff reagents [3]. 


\section{Pararosaniline}

West and Gaeke (1956) developed a method using pararosaniline and formaldehyde for the estimation of sulphur dioxide [26], and this has been modified by several investigators for determination of formaldehyde [3] and this method have been used widely. Lyles et al. (1965) reported a procedure in which formaldehyde with pararosaniline hydrochloride and dichlorosulfitemercurate II complex formed coloured product, which followed Beer's law at $560 \mathrm{~nm}$. The method is highly selective having only two interferences from other aldehydes (propionaldehyde, acetaldehyde) and these interfere only in relatively high concentrations [21]. Later work by Lahmann and Jander (1968) modified the reagent concentrations to enhance sensitivity [27]. A method derived from the above work is used today in commercially available automated analyzers [28].

Miksch et al. (1981) increased sensitivity, reproducibility and precision of pararosaniline procedure by using mercury-free sulfite reagent and reversed reagent addition. So, acidified pararosaniline and aqueous sodium sulfite are sequentially added to formaldehyde solutions. This method can be used for determination of formaldehyde in the air from nonindustrial indoor environments. Comparative data on the analysis of aqueous formaldehyde solutions shows that the modified pararosaniline method is more sensitive, more reproducible, and easier to use than the widely accepted chromotropic acid method [28].

\section{P-aminobenzene}

This reagent was proposed by Kniseley and Throop (1966), who recommended paminobenzene sulphonic acid for the spectrophotometric determination of sulphur dioxide, as it is chemically similar to pararosaniline but contains only one amino group. This method is more sensitive, and the reagents are available in higher purity [29].

Verma (1983) described a method based on the reaction between sulphur dioxide, paminoazobenzene and formaldehyde, modified for the determination of submicrogram amounts of formaldehyde in the air. A pink dye is formed when formaldehyde reacts with paminoazobenzene and sulphur dioxide in acidic medium. The pink dye shows an absorbance maximum at $505 \mathrm{~nm}$, with a molar absorptivity of $4.5 \times 10^{4} 1 . \mathrm{mol}^{-1} \cdot \mathrm{cm}^{-1}$. This method shows many interferences, from inorganic and organic compound (phenol, acetaldehyde, toluene, urea, benzene, aniline, acetone, acetic acid, nitrobenzene, formic acid, isobutyl methyl ketone, ethylamine, benzaldehyde, ethanol) [3].

Sharma and Rajput (2012) claim that instability of the colour and interferences from copollutants are the main drawbacks of the method based on p-aminoazobenzene. They investigated these inadequacies and provided reliable, accurate and cost-effective procedure in determining formaldehyde in which the formaldehyde reacts with p-aminobenzene sulphonic acid and $\mathrm{SO}_{2}$ resulting in the formation of the pinkish-red colour dye. The absorbance of pink dye was read at $510 \mathrm{~nm}$. They applied the method to different environmental samples. Several common organic species, other aldehydes and hydrocarbons do not interfere with the present method. Absorption efficiency of this method has been $95 \%$, in comparison to the original paminobenzene method, which was $85 \%$ [30].

\section{Hydrazones}

Hydrazine reagents are the most important derivatizing reagents for the determination of aldehydes and ketones in liquid and gaseous samples [31]. Hydrazones are axomethines characterized by the grouping $\mathrm{C}=\mathrm{N}-\mathrm{N}$. They are distinguished from other members of this class (imines, oximes, etc.) by the presence of the two interlinked nitrogen atoms [32]. From 
hydrazones, the currently most used reagents are 2,4-dinitrophenylhydrazine (DNPH) and methyl-2-benzothiazolone hydrazone.

\section{2,4-dinitrophenylhydrazine (DNPH)}

Among hydrazones, 2,4- dinitrophenylhydrazine (DNPH) has been established as a standard reagent by several national and international standardisation bodies. [31] The HPLC method based on pre-column derivatization with 2,4-dinitrophenylhydrazine was adopted as a standard for the determination of $0.012-2.00$ and $18.00-372.00 \mathrm{~g}^{-\mathrm{ml}^{-1}} \mathrm{HCHO}$ and $\mathrm{CH}_{3} \mathrm{CHO}$, respectively [17].

DNPH reacts with carbonyl compounds in the presence of an acidic catalyst to form the respective hydrazones. The hydrazones are separated by high-performance liquid chromatography (HPLC) [31], and HCHO-DNPH derivate is detected by UV spectroscopy at $360 \mathrm{~nm}[33]$.

The DNPH method has been used for different environmental samples including automobile exhaust, waste and drinking water and air pollution. For air monitoring, a sampling technique based on test tubes with DNPH-coated solid sorbents has been developed [34].

While workplace monitoring of formaldehyde and other short-chain-length aldehydes using the DNPH method is currently considered not to be associated with major analytical problems, some interferences associated with special applications, and analytes have become apparent in recent years [31]. The first one is that environmental measurements of formaldehyde must account for ozone interferences using an appropriate scrubber/denuder [35]. Ozone oxidizes DNPH to reaction products which are prone to interfere with the determination of carbonyls due to coelution, and the reaction products have only partly been identified [31]. The second limitation is that atmospheres with sufficient NO (when ozone scrubbers/denuders are utilized) or $\mathrm{NO}_{2}$ levels cause the formation of DNPA which may result in overestimation of formaldehyde concentrations [35] since it shows a similar chromatographic behaviour as the formaldehyde DNP-hydrazone [31]. However, chemical interferences such as reaction products of nitrogen dioxide with DNPH can be identified by dual wavelength detection [34].

\section{3-methyl-2-benzothiazolone hydrazone}

Since 1961, 3-methyl-2-benzothiazolone hydrazone hydrochloride (MBTH) has been introduced to the quantitative analysis of aldehydes [36]. The MBTH method uses the reaction of 3-methyl-2-benzothiazolinonehydrazone with low molecular weight aliphatic aldehydes to form a corresponding azide. The resulting blue complex has a characteristic absorption maximum at 628 to $629 \mathrm{~nm}$ [37].

The method is used as a standard (e.g. VDI 3862-1) for the determination of formaldehyde (NCFS 2012) or the sum of aliphatic aldehydes (VDI 1990) [37]. The method also serves as a national standard test in China [38]. MBTH has been applied for the spectrophotometric determination of trace aliphatic aldehydes in high purity epoxypropane, in sea water and cultures, in the outdoor and indoor air at low concentrations [36]. The method is easy, simple and convenient, high in sensitivity and has a low detection limit [39]. However, MBTH method has been less commonly used because it is very expensive and interferences with other lower aliphatic aldehydes have been observed, and the sample solutions should be measured immediately after sampling, which is due to instability of the MBTH-formaldehyde intermediate [24, 39, 40, 41]. 


\section{Hantzsch reaction}

One of other widely used derivatization reaction is a Hantzsch reaction, which is based on the derivatization of formaldehyde with $\beta$-diketone, in which 2,4-pentanedione (acetylacetone), 5,5-dimethyl-1,3-cyclohexanedione (dimedone), 1,3-cyclohexanedione (CHD), 4-amino3pentene-2-one (Fluoral-P), and acetoacetanilide (AAA) have been used as derivatization reagents. These methods are relatively sensitive and selective for formaldehyde [24].

\section{Methyl acetoacetate}

Methyl acetoacetate is one of the most soluble reagents in water. It is selective, sensitive and the most reactive with formaldehyde. This water-soluble reagent has been proposed by $\mathrm{Li}$ et al. (2008) for the determination of formaldehyde. This method can be directly applied to the determination of formaldehyde in natural water samples [24]. According to Li et al. (2008a), this method is simple and highly sensitive, and in their research, it was used for spectrophotometric detection of formaldehyde in a flow injection system with LED detector. The maximum absorption wavelength of the product was $375 \mathrm{~nm}$. Low molecular weight aldehydes were negligible as interferences, even at very high amounts. The proposed method is free from interference with the determination of formaldehyde in environmental waters. This method has a good recovery, from 98 to $107 \%$ [24].

\section{Fluoral-P}

Fluoral-P (4-amino-3-penten-2-one) was introduced by Compton and Purdy (1980) as a selective reagent for determination of aldehydes [42]. It is the reaction product of ammonia and 2,4-pentanedione and will hydrolyze back to the same in water. Fluoral-P must, therefore, be prepared in a non-aqueous solvent [43]. Reacting with formaldehyde, it forms a yellow complex, which is possible to analyze quantitatively by spectrophotometry. Formaldehyde reacts with Fluoral $\mathrm{P}$ and produces 3,5-diacetyl-1,4-dihydrolutidine. This compound is yellowgreenish in colour, which absorbs light at wavelengths of $412 \mathrm{~nm}$ [25].

Although Fluoral $\mathrm{P}$ is a selective reagent for determination of formaldehyde, Khanmohammadi et al. (2012) applied multivariate curve resolution alternative least squares to this method, which is a powerful method for determination of an analyte in an unknown mixture [44]. Loh et al. (2007) improved Fluoral-P method with artificial neural network computational models. A good reproducibility (2.12\%) of measurement was obtained [2]. Teixeira (2004) used Fluoral-P as a simple and sensitive method for determination of formaldehyde in ethanol fuel by solid phase spectrophotometry, coupled with a continuous flow system. The proposed method is sensitive, selective and fast. Additionally, the method has a low sample and reagents consumption, and low cost since measurements may be carried out with the help of conventional spectrophotometers. Small amounts of sample, resin and reagent are required. Another advantage of the method is the possibility of working at different formaldehyde concentration levels by selecting the sample volume depending on the analyte concentration [5].

\section{2,4-pentanedione (Acetylacetone)}

Nash (1953) first used 2,4-pentanedione (PD, acetylacetone) for the Hantzsch reaction based measurement of formaldehyde. When traces of formaldehyde are added to approximately neutral solutions of acetylacetone and ammonium salt, a yellow colour gradually develops owing to the synthesis of diacetyldihydrolutidine (DDL). Under optimum conditions, the molecular extinction in terms of formaldehyde has a smooth maximum of 8000 at $412 \mathrm{~nm}$, independent of dilution [45]. 
The 2,4-pentanedione procedure has been found useful in the analysis of formaldehyde when it is necessary to analyze under mild conditions [46]. This method is a national standard test in Chinese [38] and was widely used as a standard method for the determination of formaldehyde in the fabric owing to its high sensitivity and good reproducibility [47]. Among the spectrometric methods, the reaction with 2,4-pentanedione is the most sensitive and specific, since acetaldehyde does not interfere even when present in the concentrations 1000 times higher than formaldehyde [24]. This reagent gives negative results with all aliphatic aldehydes except formaldehyde [46]. However, the analysis procedure is relatively slow. In addition to that, acetyl acetone is more expensive and contaminates the environment [47].

\section{Catalytic reaction}

\section{Brilliant cresyl blue with sodium bromated}

This method is based on the catalytic effect of formaldehyde on the oxidation reaction of brilliant cresyl blue by sodium bromate in the sulfuric medium. It was found that the reaction of trace amount of formaldehyde can effectively catalyze the reaction of $\mathrm{NaBrO} 3$ to oxidize the yellow tar blue, and the fading speed of tar blue is proportional to the amount of formaldehyde. A linear range of determination is $0.16 \sim 2.00 \mu \mathrm{g} \cdot \mathrm{ml}^{-1}$ for formaldehyde and the detection limit is $8 \mathrm{ng} \cdot \mathrm{ml}^{-1}$. The method has been applied to the determination of formaldehyde in the water of marine seafood with satisfactory results. It is simple and fast [48].

\section{Malachite green}

Malachite green is a kind of basic triphenylmethane dye with the absorption maximum at about $617 \mathrm{~nm}$. [49] In this method, ultratrace amounts of formaldehyde inhibit the malachite green-sulfite reaction in neutral media [50].

Tang (2015) used this method for spectrophotometric kinetic determination of FA based on the catalytic effect of FA on the oxidation of MG by bromate in the presence of sulfuric acid. The analytical results were validated by comparison with acetylacetone method. Similar results in respect to the accuracy and precision were obtained [49].

In the research of Afkhami and Rezaei (1999), interference was observed from sodium chloride, sodium sulfate, sodium nitrate, ammonium nitrate, sodium acetate, sodium carbonate, glucose, and urea, even when present in 10,000-fold excess over formaldehyde. Propionaldehyde and benzaldehyde did not interfere up to 1000-fold excess over formaldehyde. Methanol, ethanol, and acetone interfered at concentrations higher than $50 \mathrm{mg} \cdot \mathrm{ml}^{-1}$. Sulfide and acetaldehyde interfered at the concentrations higher than 2 and $1.5 \mathrm{mg} \cdot \mathrm{ml}^{-1}$, respectively [50].

\section{Other reagents}

\section{$N, N$-diethyl-p-phenylenediamine (DPD)}

Mohamed et al. (2008) proposed a highly sensitive, simple and selective kinetic method for the determination of ultra-trace levels of formaldehyde and acetaldehyde based on their catalytic effect on the oxidation of N,N-diethyl-p-phenylenediamine (DPD) with hydrogen peroxide. The reaction was monitored spectrophotometrically by tracing the formation of the red-coloured oxidized product of DPD at $510 \mathrm{~nm}$, within $30 \mathrm{~s}$ of mixing reagents. The high sensitivity and selectivity of this method allow its application to rain water, mainstream smoke and disposed tips of smoked cigarettes (DTSC). The analytical results were in excellent agreements with those obtained following the standard HPLC method based on pre-column derivatization with 2,4-dinitrophenylhydrazine. Despite its simplicity and high sensitivity, the most interesting feature of the implemented method is its selectivity, especially in terms of 
ketones, alcohols, organic acids and transition metal ions that are known to react with DPD, catalyze its oxidation process and interfere in the determination of aldehydes [17].

\section{Tryptamine}

Yasri et al. (2011) developed simple, sensitive, selective and easy to perform a spectrophotometric method for the determination of formaldehyde in aqueous samples. The method is based on the formation of red-violet coloured telomere from the reaction of formaldehyde with indol-3-ethylamine (known as tryptamine), in concentrated sulphuric acid and traces $\mathrm{NaNO}_{2}$ amounts. The product that has been formed is stable at room temperature and does not interfere with substances normally present as pollutants. The method was optimized for the determination of unknown levels of formaldehyde in samples of rainwaters, wooden products and cigarette smoke. The absorbance was read at $558 \mathrm{~nm}$. This method has been developed for the determination of low-level formaldehyde [6].

\section{4-amino-5-hydrazino-3- mercapto-1,2,4-triazole (AHMT)}

The derivative reaction of $\mathrm{HCHO}$ with AHMT occurs under alkaline conditions at room temperature and forms 6-mercapto-5- triazolo[4,3-b]-s-tetrazine (MTT), which can be detected by UV/VIS spectroscopy. This method is also one of the Chinese national standard methods for the determination of $\mathrm{HCHO}$ [51].

Mimura et al. (1976) recommended this method because this method is much better in sensitivity, reproducibility and simplicity than the conventional method using chromotropic acid or acetylacetone. In addition to that, sulfite and nitrite ions, which are frequently encountered in air and water and interfere in chromotropic acid method and acetylacetone method, does not interfere in the AHMT method [52]. However, the limit of detection and the selectivity of this method are poor due to the limitation of UV/Vis absorption analysis, such as the low sensitivity and lack of characteristic spectrum [53]. The AHMT method needs a very strong base as the reaction medium, which is not desirable especially as carbonate formation will occur. Another disadvantage of this method is its expensiveness [24].

\section{Phloroglucinol}

A simple and rapid method for the spectrophotometric determination of formaldehyde was reported using 1,3,5-trihydroxybenzene (phloroglucinol) as the chromogenic agent. Formaldehyde can react with phloroglucinol in an alkaline solution or an acidic medium to produce coloured species, which allows the measurement of trace amounts of formaldehyde [54].

Under alkaline conditions, phloroglucinol was found to form an orange-red dye with formaldehyde under alkaline conditions using gelatin to stabilise the colour. The method has a detection limit of the lug with molar absorptivity of $2.1 \times 10^{4} 1 . \mathrm{mol}^{-1} \mathrm{~cm}^{-1}$ at $470 \mathrm{~nm}$. The method is free from interferences of other aldehydes, and there is no need to use corrosive chemical reagents [55].

In acidic medium, formaldehyde reacts with phloroglucinol producing a yellow dye with $\lambda_{\max }$ at $435 \mathrm{~nm}$. The working range of the method is $0-2.5 \mu \mathrm{g}$ in a final volume of $10 \mathrm{ml}$. The method has been applied for the determination of formaldehyde in a laboratory fume cupboard, auto exhaust gas, medicated toothpaste and analytical grade reagents. The method is more sensitive, compared to chromotropic acid method [56]. 


\section{Comparison of spectrophotometric methods for determination of formaldehyde in the air}

Table 1 summarises the methods commonly used for the determination of formaldehyde in the air. It can be seen, that main disadvantage of the chromotropic acid method is the use of corrosive sulphuric acid. The same disadvantage also has pararosaniline method, which includes the use of toxic tetrachloromercurate, which is in addition to that expensive. These methods also require a long time for colour development (more than one hour). According to Li et al. (2008), the chromotropic acid method and pararosaniline method provide poor limits of detection and the product of pararosaniline is sticky, which causes difficulty for handling samples. Also, the sensitivity of the method using pararosaniline-based Schiff reaction is not so good [24].

AHMT and MBTH are used as Chinese standard methods. They have higher sensitivity, compared to other methods and because of that, they are getting popular. However, both methods require relatively long reaction time $(>20)$ for the final colour development. Also, chromogenic agents are expensive [24], and therefore they are not used so often. Also, the AHMT method needs a very strong base as the reaction medium, which is not desirable especially as carbonate formation will occur [24].

In comparison with acetylacetone method, MBTH method has a higher sensitivity, and the detection limit is lower. Both precision and accuracy are good, and the results of formaldehyde determination in the air are consistent. However, the colour stability of MBTH method is lower than the acetylacetone method. [39] The AHMT method is more affected by aldehydes than acetylacetone method, [57] but does not interfere with $\mathrm{SO}_{2}{ }^{-}$and $\mathrm{NO}_{2}{ }^{-}$and $\mathrm{SO}_{3}{ }^{2-}$ as chromotropic acid method and acetylacetone method.

DNPH method is also used as a standard method, but requires HPLC before UV/VIS analysis and therefore, it is more expensive. This method requires expensive equipment and long time for colour development (3 hours) [58]. This method has also interferences from ozone oxides, $\mathrm{NO}$ and $\mathrm{NO}_{2}$. However, despite these disadvantages, this method is still widely used for the determination of formaldehyde for pollution control purposes [59].

The Schiff's method with Fuschin requires long reaction time, and the Beers low is not satisfactorily followed [55] and therefore is not very suitable for use in safety engineering.

Instability of the colour and interferences from co-pollutants are the main drawbacks of methods based on Schiff's reagent, Chomotropic acid, phenylhydrazine, MBTH and paminoazobenzene [30].

Phloroglucinol has better sensitivity than chromotropic acid, Schiff, and phenylhydrazine also has a shorter time of preparation than these methods. The main advantages of these methods are that it is specific for formaldehyde, corrosive or sophisticated reagents are not used, the method is rapid, and heating is not required. Also, the method is free from interferences of other aldehydes and several compounds that interfered in other methods. The main disadvantage of this method is low colour stability, and therefore handling this reagent is difficult. Ramachandran and Gupta (1993) enhanced the stability of this method by adding gelatine into the reaction [55].

The advantage of the p-aminobenzene method is its cost, sensitivity and availability of reagents in higher purity. However, the main drawback of this method is, that it exhibits many interferences from inorganic and organic compound (phenol, acetaldehyde, toluene, urea, benzene, aniline, acetone, acetic acid, nitrobenzene, formic acid, isobutyl methyl ketone, ethylamine, benzaldehyde, ethanol) [3]. However, it could be used in combination with chemometric methods, which would increase the selectivity of this method. 


\begin{tabular}{|c|c|c|c|c|c|c|c|c|c|}
\hline \multicolumn{10}{|c|}{$\begin{array}{l}\text { Table } 1 \text { Summary of commonly used methods for the determination of formaldehyde with } \\
\text { application in the air }\end{array}$} \\
\hline Method & $\begin{array}{l}\text { Sensiti- } \\
\text { vity }\end{array}$ & $\begin{array}{l}\text { Time } \\
\text { requir } \\
\text { ements }\end{array}$ & $\begin{array}{l}\text { Colour } \\
\text { stability }\end{array}$ & $\begin{array}{l}\text { Interferen- } \\
\text { ces }\end{array}$ & $\begin{array}{l}\text { Wave- } \\
\text { length }\end{array}$ & $\begin{array}{l}\text { Conc. } \\
\text { Limit }\end{array}$ & $\begin{array}{l}\text { Finan- } \\
\text { cial } \\
\text { require- } \\
\text { ments } \\
\text { for } \\
\text { chemical }\end{array}$ & Disadvantages & $\begin{array}{l}\text { The most } \\
\text { common } \\
\text { applica- } \\
\text { tion }\end{array}$ \\
\hline \multicolumn{10}{|c|}{ Phenolic type compounds } \\
\hline $\begin{array}{c}\text { Chromo- } \\
\text { tropic } \\
\text { acid with } \\
\mathrm{H}_{2} \mathrm{SO}_{4} \\
(\mathrm{CA}, \\
\text { Original) } \\
{[13,15]}\end{array}$ & $\begin{array}{c}1.57 \times 10 \\
41 \mathrm{~mol}^{-1} \\
\mathrm{~cm}^{-1}\end{array}$ & $\begin{array}{l}\text { Long } \\
\text { time } \\
(1 \mathrm{~h})\end{array}$ & 24 hod & $\begin{array}{c}\mathrm{SO}_{2}, \mathrm{NO}_{2}, \\
\mathrm{NO}_{3}, \\
\text { hydrocarbons }\end{array}$ & $580 \mathrm{~nm}$ & $\begin{array}{c}0.19-0.5 \\
\text { ppm }\end{array}$ & Low cost & $\begin{array}{c}\text { Use of } \\
\text { potentially } \\
\text { hazardous, } \\
\text { corrosive } \\
\text { sulphuric acid, } \\
\text { interference of } \\
\text { metal ions, } \\
\text { sugars, other, } \\
\text { long waiting } \\
\text { time }\end{array}$ & $\begin{array}{l}\text { The } \\
\text { atmosphe- } \\
\text { re, } \\
\text { combus- } \\
\text { tion } \\
\text { effluent }\end{array}$ \\
\hline $\begin{array}{c}\text { Chromo- } \\
\text { tropic } \\
\text { acid with } \\
\mathrm{HCl} \text { and } \\
\mathrm{H}_{2} \mathrm{O}_{2} \\
{[19]}\end{array}$ & $\begin{array}{c}(1-71+/- \\
0,02) \times 1 \\
0^{4} \mathrm{~mol}^{-} \\
{ }^{1} \mathrm{~cm}^{-1}\end{array}$ & $\begin{array}{l}\text { Long } \\
\text { time } \\
(1 \mathrm{~h})\end{array}$ & - & - & $575 \mathrm{~nm}$ & - & Low cost & $\begin{array}{l}\text { Long waiting } \\
\text { time }\end{array}$ & $\begin{array}{l}\text { Atmos- } \\
\text { phere, } \\
\text { combus- } \\
\text { tion } \\
\text { effluent }\end{array}$ \\
\hline \multicolumn{10}{|c|}{ Schiff reagens } \\
\hline $\begin{array}{c}\text { Fuschin } \\
\text { [55] }\end{array}$ & $\begin{array}{l}3.5 \times 10^{3} . \\
\text { L. } \mathrm{mol}^{-1} \\
\mathrm{~cm}^{-1}\end{array}$ & $\begin{array}{l}\text { Long } \\
\text { time } \\
(2 \mathrm{~h})\end{array}$ & $30 \mathrm{~min}$ & - & $550 \mathrm{~nm}$ & $0.83 \mathrm{ppm}$ & Low cost & $\begin{array}{l}\text { Beers low is not } \\
\text { satisfactorily } \\
\text { followed and } \\
\text { require long } \\
\text { waiting time }\end{array}$ & Air \\
\hline $\begin{array}{c}\text { Fuschin } \\
\text { with } \\
\text { acetone } \\
{[3,4]}\end{array}$ & $\begin{array}{c}3.5 \times 10^{3} \\
1 \mathrm{~mol}^{-1} \\
\mathrm{~cm}^{-1}\end{array}$ & $\begin{array}{l}\text { Long } \\
\text { time } \\
(3 \mathrm{~h})\end{array}$ & $30 \mathrm{~min}$ & $\begin{array}{c}\mathrm{SO}_{2}, \mathrm{NO}_{2}, \\
\text { alcohol, } \\
\text { phenol }\end{array}$ & $560 \mathrm{~nm}$ & $5 \mathrm{ppb}$ & Low cost & $\begin{array}{l}\text { Long waitting } \\
\text { time }\end{array}$ & Air \\
\hline $\begin{array}{c}\text { Pararosa- } \\
\text { niline } \\
\text { original } \\
{[21]}\end{array}$ & Low & $15 \mathrm{~min}$ & - & $\begin{array}{l}\text { Acetaldehyd } \\
\text { e, } \\
\text { propionaldeh } \\
\text { yde }\end{array}$ & $560 \mathrm{~nm}$ & $\begin{array}{c}0.01 \\
\mu \mathrm{g} \cdot \mathrm{ml}^{-1}\end{array}$ & $\begin{array}{l}\text { Expensi- } \\
\text { ve }\end{array}$ & $\begin{array}{l}\text { Tetrachloromerc } \\
\text { u-rate is costly } \\
\text { and toxic, low } \\
\text { sensitivity, } \\
\text { interferences } \\
\text { from aldehydes }\end{array}$ & Air \\
\hline $\begin{array}{c}\text { Pararosa- } \\
\text { niline } \\
\text { mercury } \\
\text { free } \\
{[28]}\end{array}$ & $\begin{array}{c}1.88 \times 10^{4} \\
1 . . \mathrm{mol}^{-1} \\
\mathrm{~cm}^{-1}\end{array}$ & $60 \mathrm{~min}$ & $120 \min$ & $\begin{array}{c}\text { Low } \\
\text { molecular } \\
\text { weight } \\
\text { aldehydes, } \\
\text { sodium } \\
\text { sulfite, } \\
\text { potassium } \\
\text { cyanide, } \\
\text { sodium } \\
\text { nitrite, } \\
\text { hydrogen } \\
\text { peroxide, } \\
\text { hydroxyla- } \\
\text { mine } \\
\end{array}$ & $570 \mathrm{~nm}$ & $\begin{array}{c}25 \\
\mathrm{ppb} / 601\end{array}$ & Low cost & $\begin{array}{l}\text { Long waiting } \\
\text { time, } \\
\text { interferences }\end{array}$ & $\begin{array}{l}\text { Air from } \\
\text { the } \\
\text { nonindu- } \\
\text { strial } \\
\text { indoor } \\
\text { environ- } \\
\text { ment, } \\
\text { water }\end{array}$ \\
\hline $\begin{array}{c}\text { P-amino- } \\
\text { benzene } \\
\text { (original) } \\
{[3]}\end{array}$ & $\begin{array}{c}4.5 \times 10^{4} \\
1 . \mathrm{mol}^{-1} \\
\mathrm{~cm}^{-1}\end{array}$ & $20 \mathrm{~min}$ & $90 \mathrm{~min}$ & $\begin{array}{l}\text { Organic and } \\
\text { inorganic } \\
\text { compounds }\end{array}$ & $505 \mathrm{~nm}$ & $\begin{array}{c}0.08-0.48 \\
\text { ppm }\end{array}$ & Low cost & $\begin{array}{l}\text { Interferences } \\
\text { from co- } \\
\text { pollutants }\end{array}$ & Air \\
\hline
\end{tabular}




\begin{tabular}{|c|c|c|c|c|c|c|c|c|c|}
\hline \multicolumn{10}{|c|}{ Table 1 Continues } \\
\hline Method & $\begin{array}{l}\text { Sensiti- } \\
\text { vity }\end{array}$ & $\begin{array}{c}\text { Time } \\
\text { requir } \\
\text { ements }\end{array}$ & $\begin{array}{l}\text { Colour } \\
\text { stability }\end{array}$ & $\begin{array}{l}\text { Interferen- } \\
\text { ces }\end{array}$ & $\begin{array}{l}\text { Wave- } \\
\text { length } \\
(\mathbf{n m})\end{array}$ & $\begin{array}{l}\text { Conc. } \\
\text { Limit }\end{array}$ & $\begin{array}{c}\text { Finan- } \\
\text { cial } \\
\text { require- } \\
\text { ments } \\
\text { for } \\
\text { chemical }\end{array}$ & Disadvantages & $\begin{array}{l}\text { The most } \\
\text { common } \\
\text { applica- } \\
\text { tion }\end{array}$ \\
\hline $\begin{array}{c}\text { P-amino- } \\
\text { benzene } \\
\text { sulphonic } \\
\text { acid } \\
{[30]}\end{array}$ & $\begin{array}{c}1.5 \times 10^{3} \\
1 . \mathrm{mol}^{-1} \\
\mathrm{~cm}^{-1}\end{array}$ & $\begin{array}{c}20-25 \\
\min \end{array}$ & $60 \mathrm{~min}$ & $\begin{array}{l}\text { Organic and } \\
\text { inorganic } \\
\text { compounds }\end{array}$ & $510 \mathrm{~nm}$ & $\begin{array}{c}0.072- \\
0.38 \mathrm{ppm}\end{array}$ & Low cost & $\begin{array}{l}\text { Interferences } \\
\text { from co- } \\
\text { pollutants }\end{array}$ & $\begin{array}{c}\text { Air, } \\
\text { automobi- } \\
\text { le exhaust }\end{array}$ \\
\hline \multicolumn{10}{|c|}{ Hydrazones } \\
\hline $\begin{array}{c}\text { МВТН } \\
{[3,12,37} \\
39,]\end{array}$ & $\begin{array}{c}6.5 \times 10^{4} \\
1 . \mathrm{mol}^{-1} \\
\mathrm{~cm}^{-1}\end{array}$ & $10 \mathrm{~min}$ & $4 \mathrm{~h}$ & $\begin{array}{l}\text { Other lower } \\
\text { aliphatic } \\
\text { aldehydes }\end{array}$ & $670 \mathrm{~nm}$ & $0.05 \mathrm{ppm}$ & $\begin{array}{l}\text { Very } \\
\text { expensi- } \\
\text { ve }\end{array}$ & $\begin{array}{l}\text { Stability is not } \\
\text { good as in } \\
\text { acetylacetone } \\
\text { method, } \\
\text { interferences } \\
\text { from lower } \\
\text { aliphatic } \\
\text { aldehydes, } \\
\text { expensiveness }\end{array}$ & $\begin{array}{c}\text { Epoxypro } \\
\text {-pane, } \\
\text { seawater, } \\
\text { outdoor } \\
\text { and } \\
\text { indoor air }\end{array}$ \\
\hline $\begin{array}{c}\text { DNPH } \\
{[58,60]}\end{array}$ & $\begin{array}{c}1.76 \times 10^{4} \\
1 . \mathrm{mol}^{-1} \\
\mathrm{~cm}^{-1}\end{array}$ & $\begin{array}{l}\text { Long } \\
\text { time }\end{array}$ & - & $\begin{array}{c}\text { Ozone } \\
\text { oxides, } \mathrm{NO}, \\
\mathrm{NO}_{2}\end{array}$ & $357 \mathrm{~nm}$ & $\begin{array}{c}0.012- \\
2.00 \text { and } \\
18.00- \\
372 \\
\mathrm{~g} \mathrm{ml}^{-1}\end{array}$ & $\begin{array}{l}\text { Expensi- } \\
\text { ve }\end{array}$ & $\begin{array}{l}\text { Need to use } \\
\text { HPLC before } \\
\text { UV/VIS } \\
\text { spectroscopy, } \\
\text { expensiveness }\end{array}$ & $\begin{array}{c}\text { Polysac- } \\
\text { chharides, } \\
\text { Automo- } \\
\text { bile } \\
\text { exhaust } \\
\text { water, air } \\
\text { pollution }\end{array}$ \\
\hline \multicolumn{10}{|c|}{ Hantzsch reaction } \\
\hline $\begin{array}{c}\text { Acetyla- } \\
\text { cetone } \\
\text { (AA) } \\
{[59]}\end{array}$ & $\begin{array}{c}\text { High } \\
\text { sensitivi- } \\
\text { ty }\end{array}$ & $\begin{array}{c}10 \mathrm{~min} \\
+ \\
\text { cooling }\end{array}$ & - & $\begin{array}{c}\mathrm{NO}_{2}, \mathrm{SO}_{3} \\
\text { ions; } \\
\text { acrolein, } \\
\text { acetaldehyde } \\
\text { at } 100 \mathrm{pm},\end{array}$ & - & $0.1 \mathrm{ppm}$ & - & $\begin{array}{l}\text { Slow procedure, } \\
\text { acetyl acetone is } \\
\text { more expensive } \\
\text { and contaminates } \\
\text { environment }\end{array}$ & $\begin{array}{c}\text { Air, fabric } \\
\text { owning }\end{array}$ \\
\hline \multicolumn{10}{|c|}{ Other reagens } \\
\hline$\underset{[57]}{\text { AHMT }}$ & $\begin{array}{l}2.1 \mathrm{x} \\
\text { greater } \\
\text { than AA } \\
\text { method }\end{array}$ & $20 \min$ & - & $\begin{array}{c}\text { Acrolein, } \\
\text { acetaldehyde } \\
\text { propionalde- } \\
\text { hyde, } \mathrm{n}- \\
\text { butyraldehy- } \\
\text { de, at } 1 \mathrm{ppm} \\
\end{array}$ & $550 \mathrm{~nm}$ & $0.05 \mathrm{ppm}$ & $\begin{array}{l}\text { Very } \\
\text { expensi- } \\
\text { ve }\end{array}$ & $\begin{array}{l}\text { Expensiveness, } \\
\text { interferences } \\
\text { from other } \\
\text { aldehydes }\end{array}$ & Air, water \\
\hline $\begin{array}{l}\text { Phloro- } \\
\text { glucinol } \\
\text { in } \\
\text { alkaline } \\
\text { condi- } \\
\text { tions } \\
{[55]}\end{array}$ & $\begin{array}{l}2.1 \times 10^{4} \\
\text { L.mol }{ }^{-1} \\
\mathrm{~cm}^{-1}\end{array}$ & Low & Unstable & $\begin{array}{l}\text { Free from } \\
\text { interferences } \\
\text { of aldehydes }\end{array}$ & $470 \mathrm{~nm}$ & $\begin{array}{c}0.1-2 \\
\mu \mathrm{g} . \mathrm{ml}^{-1}\end{array}$ & Low cost & $\begin{array}{c}\text { The colour is } \\
\text { unstable }\end{array}$ & $\begin{array}{l}\text { Air, } \\
\text { distillery } \\
\text { waste, } \\
\text { polluted } \\
\text { river } \\
\text { water, } \\
\text { coke oven } \\
\text { effluent }\end{array}$ \\
\hline
\end{tabular}

\section{CONCLUSION}

Nowadays, there are many spectrophotometric methods for the determination of formaldehyde in the air. According to the properties mentioned in Table 1, p-aminobenzene 
method and phloroglucinol method seem to be the most suitable for the determination of formaldehyde in air in safety engineering, particularly in terms of sensitivity, cost, the toxicity of the chemicals used and time requirements. Phloroglucinol is more suitable in terms of interferences and requires less time for colour development. However, it is unstable, and thus the handling with this reagent is more complicated. However, there is a possibility to improve the stability of this method using gelatine. Because of this disadvantage, it is more commonly used for automated analyses. On the other hand, P-aminobenzene needs longer time for colour development, and exhibits many interferences and a lower detection limit. The interferences could be improved by implementing thechemometric methods. Therefore, it could be interesting to investigate the efficiency of the p-aminobenzene method in combination with chemometric analysis.

\section{Acknowledgement}

This research output was supported by the Slovak Research and Development Agency under contract No. APVV-16-0223. This research output was also supported by the Cultural and Education Agency of the Ministry of Education, Science, Research and Sport of the Slovak Republic (KEGA 030UMB-4/2017) and by the Slovak University of Technology (Program for support of young scientists).

\section{References}

[1] LITEPLO, R. G., BEAUCHAMP, R., MEEK, M. E. 2002. Formaldehyde. Concise International Chemical Assessment Document 40. World Health Organization, Geneva, 2002. 72 p. ISBN 9241530405

[2] LOH, H. C., CHONG, K. W., AHMAD, M. 2007. Quantitative Analysis of Formaldehyde Using UV-VIS Spectrophotometer Pattern Recognition and Artificial Neural Networks. Analytical letters, 40(2), 281-293. ISSN 0003-2719

[3] VERMA, P., \& GUPTA, V. K. 1983. Spectrophotometric determination of formaldehyde in air. Talanta, 30(6), 443-445. ISSN 0039-9140

[4] RAYNER, A. C., AND C. M. JEPHCOTT. 1961. Microdetermination of formaldehyde in air. Analytical Chemistry, 33(4), 627-630. ISSN 0003-2700

[5] TEIXEIRA, L. S., LEÃO, E. S., DANTAS, A. F., PINHEIRO, H. L., COSTA, A. C., DE ANDRADE, J. B. 2004. Determination of formaldehyde in Brazilian alcohol fuels by flowinjection solid phase spectrophotometry. Talanta, 64(3), 711-715. ISSN 0039-9140

[6] YASRI, N. G., SEDDIK, H., \& MOSALLB, M. A. 2015. Spectrophotometric determination of formaldehyde based on the telomerization reaction of tryptamine. Arabian Journal of Chemistry, 8(4), 487-494. ISSN 1878-5352

[7] ZHANG, L. 2018. Formaldehyde: Exposure, Toxicity and Health Effects. 1st ed. Royal Society of Chemistry, 2018. 389 p. ISBN 978-1782629733

[8] CONNOLlY, A. J., FINKBEINER, W. E., URSELL, P. C., \& DAVIS, R. L. 2015. Autopsy pathology: a manual and atlas. 3rd ed. Elsevier Health Sciences, 2015. 400 p. ISBN 9780323287807

[9] HEALTH. DIVISION OF PHYSICAL SCIENCES. 1994. NIOSH, Manual of Analytical Methods $(M N A M)$. 4th ed. US Department of Health and Human Services, Public Health Service, Centers for Disease Control and Prevention, National Institute for Occupational Safety and Health, Division of Physical Sciences and Engineering, 1994. 382 p. NIOSH Publication No. 96-135

[10] ZHAO, J., FAN, B. 2006. Spectrophotometric Determination Method of Formaldehyde [J]. Guangdong Trace Elements Science, 13(2), 17-22. ISSN 1006-446X

[11] GASPARINI, F., WEINERT, P. L., LIMA, L. S., PEZZA, L., \& PEZZA, H. R. 2008. A simple and green analytical method for the determination of formaldehyde. Journal of the Brazilian Chemical Society, 19(8), 1531-1537. ISSN 1678-4790 
[12] SAWICKI, E., HAUSER, T. R., \& MCPHERSON, S. 1962. Spectrophotometric Determination of Formaldehyde and Formaldehyde-Releasing Compounds with Chromotropic Acid, 6-Amino-1naphthol-3-sulfonic Acid (J Acid), and 6-Anilino-1-napthol-3-sulfonic Acid (Phenyl J Acid). Analytical Chemistry, 34(11), 1460-1464. ISSN 0003-2700

[13] WEST, P. W., \& SEN, B. 1956. Spectrophotometric determination of traces of formaldehyde. Fresenius' Zeitschrift für analytische Chemie, 153(3), 177-183. ISSN 1432-1130

[14] POCKARD, A. D., \& CLARK, E. R. 1984. The determination of traces of formaldehyde. Talanta, 31(10), 763-771. ISSN 0039-9140

[15] ALTSHULLER, A. P., MILLER, D. L., \& SLEVA, S. F. 1961. Determination of formaldehyde in gas mixtures by the chromotropic acid method. Analytical Chemistry, 33(4), 621-625. ISSN 00032700

[16] Gigante, A. C., GOTARDO, M. A., TOGNOlLI, J. O., PEZZA, L., \& PEZZA, H. R. 2004. Spectrophotometric determination of formaldehyde with chromotropic acid in phosphoric acid medium assisted by microwave oven. Microchemical Journal, 77(1), 47-51. ISSN 0026-265X

[17] MOHAMED, A. A., MUBARAK, A. T., MARESTANI, Z. M., \& FAWY, K. F. 2008. Highly sensitive and selective catalytic determination of formaldehyde and acetaldehyde. Talanta, 74(4), 578-585. ISSN 0039-9140

[18] BRICKER, C. E., \& JOHNSON, H. R. 1945. Spectrophotometric method for determining formaldehyde. Industrial \& Engineering Chemistry Analytical Edition, 17(6), 400-402. ISSN 00964484

[19] FAGNANI, E., MELIOS, C. B., PEZZA, L., \& PEZZA, H. R. 2003. Chromotropic acidformaldehyde reaction in strongly acidic media. The role of dissolved oxygen and replacement of concentrated sulphuric acid. Talanta, 60(1), 171-176. ISSN 0039-9140

[20] GEORGHIOU, P. E., HO, C. K. 1989. The chemistry of the chromotropic acid method for the analysis of formaldehyde. Canadian Journal of Chemistry, 67(5), 871-876. ISSN 1480-3291

[21] LYLES, G. R., DOWLING, F. B., BLANCHARD, V. J. 1965. Quantitative determination of formaldehyde in the parts per hundred million concentration level. Journal of the Air Pollution Control Association, 15(3), 106-108. ISSN 0002-2470

[22] JENDRAL, J. A., MONAKHOVA, Y. B., LACHENMEIER, D. W. 2011. Formaldehyde in alcoholic beverages: large chemical survey using purpald screening followed by chromotropic acid spectrophotometry with multivariate curve resolution. International journal of analytical chemistry, 2001, 1-11. ISSN 1687-8779

[23] SCHIFF, H. 1866. Eine neue reihe organischer diamine. Justus Liebigs Annalen der Chemie, 140(1), 92-137. ISSN 0075-4617

[24] LI, Q., SRITHARATHIKHUM, P., OSHIMA, M., MOTOMIZU, S. 2008. Development of novel detection reagent for simple and sensitive determination of trace amounts of formaldehyde and its application to flow injection spectrophotometric analysis. Analytica Chimica Acta, 612(2), 165172. ISSN 0003-2670

[25] PINHEIRO, H. L., DE ANDRADE, M. V., DE PAULA PEREIRA, P. A., \& DE ANDRADE, J. B. 2004. Spectrofluorimetric determination of formaldehyde in air after collection onto silica cartridges coated with Fluoral P. Microchemical Journal, 78(1), 15-20. ISSN 0026-265X

[26] WEST, P. W., \& GAEKE, G. C. 1956. Fixation of sulfur dioxide as disulfitomercurate (II) and subsequent colorimetric estimation. Analytical Chemistry, 28(12), 1816-1819. ISSN 0003-2700

[27] LAHMANN, E., JANDER, K. 1968. Formaldehyd-bestimmungen in strassenluft. Gesundheitsingenieur, (89) 18-21. ISSN 0016-9277

[28] MIKSCH, R. R., ANTHON, D. W., FANNING, L. Z., HOLlOWELL, C. D., REVZAN, K., GLANVILLE, J. 1981. Modified pararosaniline method for the determination of formaldehyde in air. Analytical Chemistry, 53(13), 2118-2123. ISSN 0003-2700

[29] KNISELEY, S. J., \& THROOP, L. J. 1966. p-Amonoazobenzene for the spectrophotometric determination of sulfur dioxide. Analytical chemistry, 38(9), 1270. ISSN 0003-2700

[30] SHARMA, P. K., RAJPUT, S. K. 2012. Indirect Spectrophotometric Determination of Formaldehyde with Sulphur Dioxide in Air Samples using p-Aminobenzene Sulphonic Acid. Asian Journal of Research in Chemistry, 5(2), 183-186. ISSN 0974-4150

[31] SCHULTE-LADBECK, R., LINDAHL, R., LEVIN, J. O., KARST, U. 2001. Characterization of 118 
chemical interferences in the determination of unsaturated aldehydes using aromatic hydrazine reagents and liquid chromatography. Journal of Environmental Monitoring, 3(3), 306-310. ISSN $1464-0325$

[32] SINGH, R. B., JAIN, P., SINGH, R. P. 1982. Hydrazones as analytical reagents: a review. Talanta, 29(2), 77-84. ISSN 0039-9140

[33] WANG, H., DING, J., DU, X., SUN, X., CHEN, L., ZENG, Q., DING, L. 2012. Determination of formaldehyde in fruit juice based on magnetic strong cation-exchange resin modified with 2, 4dinitrophenylhydrazine. Food chemistry, 131(1), 380-385. ISSN 0308-8146

[34] SANDNER, F., DOTT, W., \& HOLLANDER, J. 2001. Sensitive indoor air monitoring of formaldehyde and other carbonyl compounds using the 2, 4-dinitrophenylhydrazine method. International journal of hygiene and environmental health, 203(3), 275-279. ISSN 14384639

[35] HERRINGTON, J. S., HAYS, M. D. 2012. Concerns regarding 24-h sampling for formaldehyde, acetaldehyde, and acrolein using 2, 4-dinitrophenylhydrazine (DNPH)-coated solid sorbents. Atmospheric Environment, 55, 179-184. ISSN 1352-2310

[36] BARARY, M. H., EL-YAZBI, F. A., \& BEDAIR, M. A. 1991. Spectrophotometric determination of aldehydes in alcohols. Analytical letters, 24(5), 857-869. ISSN 0003-2719

[37] GIESEN, R., SCHRIPP, T., MARKEWITZ, D., MEYER, B., SCHWAB, H., UHDE, E., SALTHAMMER, T. 2016. Comparison of methods for the determination of formaldehyde in air. Analytical Letters, 49(10), 1613-1621. ISSN 0003-2719

[38] JIN, S. G., WANG, H. Y., LI, H., LIU, H. Y. 2012. The Comparison between Chemical spectrophotometry and Instrument method to determine the formaldehyde concentration of the indoor air. In: 2012 International Conference on Biomedical Engineering and Biotechnology, pp. 1787-1790. ISBN 978-0-7695-4706-0.

[39] ZHANG, J., DONG S., JIN Z. 2004. Study on MBTH and acetyl acetone spectrophotometric methods for determination of formaldehyde in air. Environmental Science and Technology. 27(4), 33-36. ISSN 1520-5851

[40] SAWICKI, E., HAUSER, T. R., STANLEY, T. W., ELBERT, W. 1961. The 3-methyl-2benzothiazolone hydrazone test. Sensitive new methods for the detection, rapid estimation, and determination of aliphatic aldehydes. Analytical Chemistry, 33(1), 93-96. ISSN 0003-2700

[41] CHAN, W. H., SHUANG, S., \& CHOI, M. M. 2001. Determination of airborne formaldehyde by active sampling on 3-methyl-2-benzothiazolinone hydrazone hydrochloride-coated glass fibre filters. Analyst, 126(5), 720-723. ISSN 0003-2654

[42] COMPTON, B. J., \& PURDY, W. C. 1980. Fluoral-P, a member of a selective family of reagents for aldehydes. Analytica Chimica Acta, 119(2), 349-357. ISSN 0003-2670

[43] LI, J., DASGUPTA, P. K., LUKE, W. 2005. Measurement of gaseous and aqueous trace formaldehyde: revisiting the pentanedione reaction and field applications. Analytica Chimica Acta, 531(1), 51-68. ISSN 0003-2670

[44] KHANMOHAMMADI, M., DALALI, N., KARAMI, F., GARMARUDI, A. B., NEMATI, H. 2012. Quantitative determination of formaldehyde by spectrophotometry utilizing multivariate Curve resolution alternating least squares. Bulletin of the Chemical Society of Ethiopia, 26(2). ISSN 1011-3924

[45] NASH, T. 1953. The colorimetric estimation of formaldehyde by means of the Hantzsch reaction. Biochemical Journal, 55(3), 416. ISSN 1470-8728

[46] SAWICKI, E., CARNES, R. A. 1968. Spectrophotofluorimetric determination of aldehydes with dimedone and other reagents. Microchimica Acta, 56(1), 148-159. ISSN 1436-5073

[47] FENG, S., FAN, J., WANG, A., CHEN, X., HU, Z. 2004. Kinetic Spectrophotometric Determination of Formaldehyde in Fabric and Air by Sequential Injection Analysis. Analytical Letters, 37(12), 2545-2555. ISSN 0003-2719

[48] GUO, Y. L., YAN, H. T., PEI, R. H., JIA, S. Y. 2006. Kinetic spectrophotometric determination of formaldehyde by catalytic oxidation of brilliant cresyl blue with sodium bromate. Chinese Journal of Analysis Laboratory, 25(10), 92. ISSN 1000-0720 
[49] TANG, Y., CHEN, H., WENG, C., TANG, X., ZHANG, M., HU, T. 2015. Determination of trace amount of formaldehyde base on a bromate-Malachite Green system. Spectrochimica Acta Part A: Molecular and Biomolecular Spectroscopy, 135, 506-510. ISSN 1386-1425

[50] AFKHAMI, A., REZAEI, M. 1999. Sensitive spectrophotometric determination of formaldehyde by inhibition of the malachite green-sulfite reaction. Microchemical journal, 63(2), 243-249. ISSN 0026-265X

[51] QUESENBERRY, M. S., LEE, Y. C. 1996. A rapid formaldehyde assay using purpald reagent: application under periodation conditions. Analytical biochemistry, 234(1), 50-55. ISSN 0003-2697

[52] MIMURA, H., KANEKO, M., NISHIYAMA, N., FUKUI, S., KANNO, S. 1976. Determination of formaldehyde by the 4-amino-3-hydrazino-5-mercapto-1,2,4-triazol method (AHMT method). $J$. Hyg. Chem.. 22. 39-41. ISSN 1000-8020

[53] MA, P., LIANG, F., WANG, D., YANG, Q., DING, Y., YU, Y., WANG, X. 2015. Ultrasensitive determination of formaldehyde in environmental waters and food samples after derivatization and using silver nanoparticle assisted SERS. Microchimica Acta, 182(3-4), 863-869. ISSN 1436-5073

[54] LI, Z., MA, H., LU, H., TAO, G. 2008. Determination of formaldehyde in foodstuffs by flow injection spectrophotometry using phloroglucinol as chromogenic agent. Talanta, 74(4), 788-792. ISSN 0039-9140

[55] RAMACHANDRAN, K. N., GUPTA, V. K. 1993. A new reagent system for detection and determination of formaldehyde in environment. Chemia Analityczna, 38(4), 513-518. ISSN 00092223

[56] GAYATHRI, N., BALASUBRAMANIAN, N. 2000. Spectrophotometric determination of formaldehyde. Analytical Letters, 33(14), 3037-3050. ISSN 0003-2719

[57] SUGITA, T., INSHIWATA, H., YOSHIKIRA, K. 1988. Comparative studies on the determination of formaldehyde by the acetylacetone and 4-amino-3-hydrazino-5-mercapto-1,2,4-triazole methods. J. Food Hg. Soc. Japan, 29(4), 273-279. ISSN 1882-1006

[58] TUMMALAPALLI, M., \& GUPTA, B. 2015. A UV-vis spectrophotometric method for the estimation of aldehyde groups in periodate-oxidized polysaccharides using 2, 4-dinitrophenyl hydrazine. Journal of Carbohydrate Chemistry, 34(6), 338-348. ISSN 0732-8303

[59] SOLIDUM, J., BELMONTE, J.K., CATUGDA, F., CRUZ, A.C., GULLA, D.V., IRINGAN, J., LLAMELO, P., QUIMOSING, K., VENTURA, K.M. 2012. Quantitative determination of formaldehyde in air in selected laboratories in the University of the Philippines Manila-Philippine General Hospital. Int. Proc. Chem. Biol. Environ. Eng., 37, 60-64. ISSN 2010-4618

[60] PÖTTER, W., \& KARST, U. 1996. Identification of Chemical Interferences in Aldehyde and Ketone Determination Using Dual-Wavelength Detection. Analytical Chemistry, 68(19), 33543358. ISSN 0003-2700

\section{ORCID}

$\begin{array}{ll}\text { Martina Hladová } & 0000-0003-4281-9834 \\ \text { Jozef Martinka } & 0000-0002-0060-5785 \\ \text { Peter Rantuch } & 0000-0001-5826-8323 \\ \text { Aleš Nečas } & 0000-0003-3626-7092\end{array}$

